\title{
The New Normal in Dentistry after COVID-19 Outbreak
}

\author{
Amit Tirth ${ }^{1}$, Md Nazamuddin Tafadar ${ }^{2}$, Ravishankar Lingesha Telgi ${ }^{3}$, Monika ${ }^{4}$ \\ ${ }^{1}$ Professor, ${ }^{2,4}$ Postgraduate Student, ${ }^{3}$ Professor and Head, Department of Public Health Dentistry, Kothiwal Dental \\ College and Research Centre, Moradabad, India, ${ }^{3}$ Department of Public Health Dentistry, Kothiwal Dental College and \\ Research Center, Moradabad, India
}

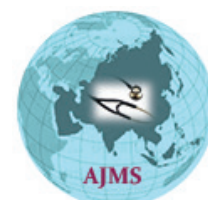

A B S T R A C T

The outbreak of SARS-COV2 responsible COVID-19 disease created a worldwide health emergency. After its first case was accounted for in 2019,31st December by World Health Organization in Wuhan city of china, and afterward spreading in different nations, with India surpassing cases even the inception nation as on twentieth of May 2020. The WHO declared the disease as pandemic way back and countries over the world adopting lockdown and contact tracing to limit the contagion. The virus transmits person-to-person predominantly through respiratory routes through direct contact, droplets and possibly aerosols. Because of the unique nature of practice in dentistry, most procedure generate significant amount of aerosols and droplets, posing a possible risk of infection transmission. Understanding the concern of risk of transmission in dental practice, this literature is aimed to discuss the possible risk associated with practice and aim to raise awareness of the same with preventive measures, especially amidst pandemic in day to day practice.

Key words: Aerosol;Covid-19;High Volume Evacuator (HVE); Management; Preprocedural mouth rinse; Triage questionnaire

\section{INTRODUCTION}

Coronaviruses is a non-segmented large group, positive-sense RNA genome of $\sim 30 \mathrm{~kb}$ that belongs to order Nidovirales which include Coronaviridae, Arteriviridae, Mesoniviridae, and Roniviridae families. ${ }^{1}$ The two sub-family of Coronaviridae are Torovirinae and Coronavirinae. ${ }^{1}$ People with COVID-19 show symptoms of fever or chills, cough, difficulty breathing, fatigue, muscle or body aches, headache, sore throat, new loss of taste or smell, congestion or runny nose, nausea or vomiting and diarrhoea. ${ }^{2}$ Incubation period can go from 2 to 14 days with most patients only developing mild symptoms. ${ }^{2}$ The far-reaching dynamics and a relatively high R0 of 2-2.5 of COVID-19 radiated it from Wuhan to whole China and rest of the world.

Given the outbreak and transmission of SARS-CoV-2 and reports of its spread to health care providers, ${ }^{4}$ health

\section{Access this article online}

Website:

http://nepjol.info/index.php/AJMS DOI: 10.3126/ajms.v11i5.29549

E-ISSN: 2091-0576

P-ISSN: 2467-9100

Copyright (c) 2020 Asian Journal of Medical Sciences

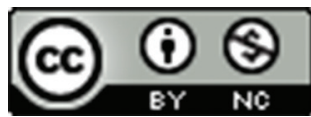

This work is licensed under a Creative Commons Attribution-NonCommercial 4.0 International License.

\section{Address for Correspondence:}

Dr Md NazamauddinTafadar, Postgraduate Student, Kothiwal Dental College and Research Center, Moradabad-244001, India.

Phone: +91-9508063656. E-mail: docnazamtafadar@gmail.com 
of the virus because of the unique nature of dental interventions which include enormous aerosol generation and dental staff proximity to the patient's oropharyngeal region.

Due to immediate contact transmission, the mucosa of the mouth has been perceived as a conceivably high-risk of SARS-CoV-2 disease, likewise contaminated hands, contamination of ambiance and instruments, dental apparatuses, and surfaces by the use of handpieces with irrigation and air blower favoring diffusion of aerosol particles of blood, saliva, and secretions could encourage infection transmission to patients. ${ }^{7}$ Considering all these, dental professionals even dealing with emergency cases in dental setting need preventive measures to be adopted in order to limit and restrict the contagion.

\section{MANAGEMENT RECOMMENDATIONS FOR CLINIC SETTING DURING PANDEMIC}

\section{Triage area}

Dental clinics are recommended to establish pre-check triages to record the temperature of every staff and patient as a routine procedure based on the questionnaire (Table 1) to evaluate the risk. Telephonic screening can be performed during the time of scheduling appointments. Staff members who are screening patients to remain 6 feet away from the patient until screening determines a patient is symptom-free and afebrile. ${ }^{8}$ Patients and their accompanying persons are provided with medical masks and temperature measurement once they enter the hospital or clinic setup. ${ }^{4}$ Body temperature should be registered, possibly with a contact-free forehead thermometer, and the presence of suspect symptoms (coughing, sneezing, respiratory difficulty) should be excluded. ${ }^{9}$ If a patient had a positive history of contact and/or symptoms, no treatment should be performed, and the patient should be reported to the authorities, to quickly impose quarantine and/or hospitalization depending on the severity of the situation. ${ }^{5}$ Based on the assessment of emergency questionnaire (Table 2), clinicians can measure the severity of the dental condition and make a decision to either provide or concede dental care.Also, an overview of COVID-19 and its dental management with certain specific measuressummarized in Figure 1.

\section{Personal hand hygiene and protection}

Hand hygiene practice is important and effective measure for reducing SARS-CoV-2 transmission. ${ }^{4,5}$ Dental professionals should wash their hands before patient examination, before dental procedures, and non-disinfected surfaces or equipment and avoid touching their own eyes, mouth, and nose. A protocol of two-beforehand-

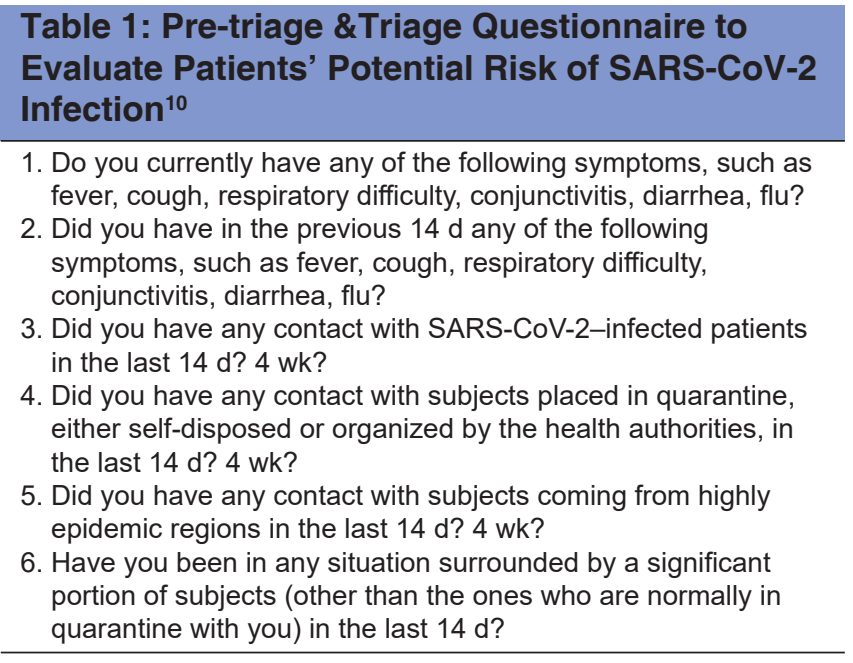

Table 2: Assessment of a true emergency questionnaire

Assessment of true emergency

1. Are you in pain?

2. What is your level of pain on a scale of $0-10$ ?

$\begin{array}{lllllllllll}0 & 1 & 2 & 3 & 4 & 5 & 6 & 7 & 8 & 9 & 10\end{array}$

\begin{tabular}{|c|c|c|c|c|c|}
\hline$\Gamma$ & T & $T$ & $T$ & $T$ & $T$ \\
\hline $\begin{array}{l}\text { No } \\
\text { pain }\end{array}$ & mild & moderate & severe & $\begin{array}{l}\text { very } \\
\text { severe }\end{array}$ & $\begin{array}{l}\text { worst possible } \\
\text { pain }\end{array}$ \\
\hline (0) & $(1-3)$ & $(3-5)$ & $(5-7)$ & $(7-9)$ & (10) \\
\hline
\end{tabular}

3. When did the pain begin?

4. Do you have dental abscess (are your gums and/or face swollen?) Yes/No

If Yes, when did you first notice the swelling? .......

5. Do you have fever?

6. Are you having any trouble swallowing?

7. Are you having any trouble opening your mouth? Yes/No

8. Did you experience any trauma? Yes/No

If Yes, please describe the trauma.....

three-after hand washing was suggested, to reinforce the compliance of hand washing. ${ }^{5}$

As SARS-Cov-2 preferably transmits through airborne droplet and is considered as the main route of spread, particularly in dental clinics and hospitals, barrier-protection equipment, including protective eyewear, masks, gloves, caps, face shields, and protective outwear, is strongly recommended for all healthcare givers within the clinic/ hospital settings during the epidemic period of $2019-\mathrm{nCoV}^{4,5}$

\section{Preprocedural mouth rinse}

Previous studies reported that SARS-CoV is highly susceptible to preprocedural mouth rinse of povidine and would be most useful in cases when rubber dam cannot be used. ${ }^{5} \mathrm{As} 2019-\mathrm{nCoV}$ is vulnerable to oxidation, preprocedural mouth rinse containing oxidative agents such as $1 \%$ hydrogen peroxide or $0.2 \%$ povidone is recommended, for the purpose of reducing the salivary 


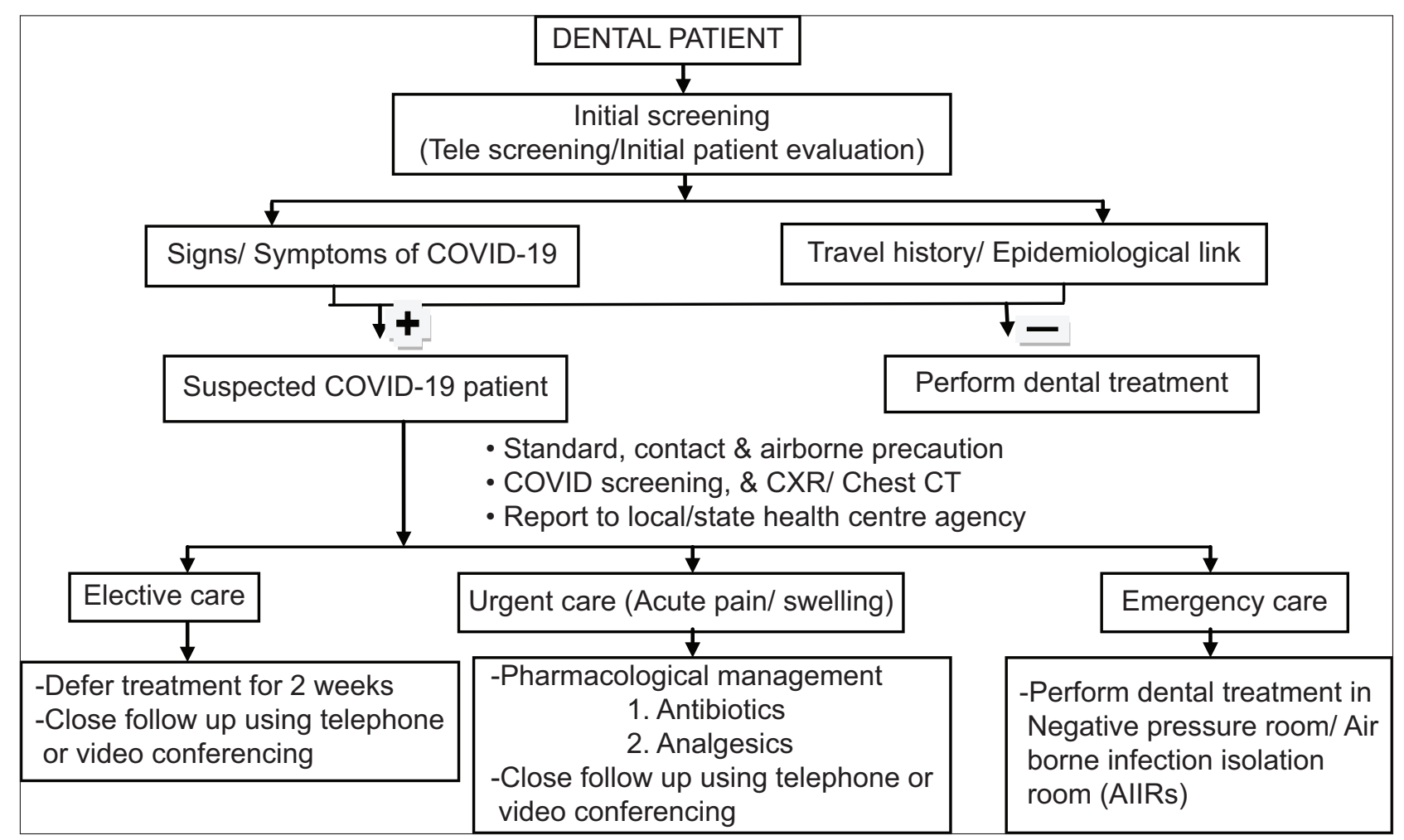

Figure 1: An overview of patient screening for COVID-19 and dental management

load of oral microbes, including potential 2019-nCoV carriage. $^{5}$

\section{Aerosol \& high volume evacuator (HVE) device}

Aerosol generation in dental care due to its unique nature of practice produce an enormous risk of infection and concern over it. Within the dental setting, the extreme production and persistence of aerosols during dental procedures expose dental workers to the risk of inhaling small particles and droplets, which are reported to potentially carry microorganisms such as bacteria and viruses. ${ }^{11}$ Studies have suggested that 2019$\mathrm{nCoV}$ may be airborne through aerosols formed during medical procedures. ${ }^{12} \mathrm{~A}$ true aerosol or droplet nuclei may be present within the air of the operatory for up to 30 minutes after a procedure ${ }^{13}$ and thus if the operator removes the protective barrier after completion of the procedure, the potential for contact with airborne contamination remains. So such treatment procedure with significant generation of aerosol may pose significant risks both for practitioners and patients.

Frequently employed methods for removing airborne contamination from the air of the treatment room are with the use of a high efficiency particulate air (HEPA) filter and the use of ultraviolet, or UV, chambers in the ventilation system but they are expensive and takes extended period for treatment, making inappropriate to use in almost all dental setting. ${ }^{14}$ The use of a high-volume evacuator, or HVE, has been shown to reduce the contamination arising from the operative site by more than 90 percent. ${ }^{15}$ The usual HVE used in dentistry has a large opening (usually 8 millimeters or greater) and is attached to an evacuation system that will remove a large volume of air (up to 100 cubic feet of air per minute). ${ }^{14}$ The small opening of a saliva ejector doesn't remove a large enough volume of air to be classified as an HVE. ${ }^{14}$

To limit the aerosol generation or spatter, rubber dam isolation and high-volume saliva ejectors are considered to be "appropriate work practices"-precautions that's recommended for dental practices. ${ }^{5,16}$ Table 3 lists the available methods of reducing aerosols and splatter contamination, as well as their relative effectiveness and costs. $^{14}$

\section{Disinfection of the clinic settings}

Human coronaviruses such as SARS-CoV-2, Middle East Respiratory Syndrome coronavirus (MERS-CoV), or endemic human coronaviruses $(\mathrm{HCoV})$ can persist on surfaces like metal, glass, or plastic for up to a couple of days. ${ }^{17}$ Moreover, it was shown that at room temperature $\mathrm{HCoV}$ remains infectious from 2 hour up to 9 days, and persists better at 50\% compared with 30\% relative humidity. ${ }^{18}$ Thus, keeping a clean and dry environment in the dental office would help decrease the persistence 


\begin{tabular}{|c|c|c|}
\hline Device & Advantages & Disadvantages \\
\hline $\begin{array}{l}\text { Barrier protection-masks, gloves } \\
\text { and eye protection }\end{array}$ & $\begin{array}{l}\text { Part of "standard precautions," } \\
\text { Inexpensive }\end{array}$ & $\begin{array}{l}\text { Masks will only filter out } 60 \text { to } 95 \\
\text { percent of aerosols, subject to leakage if not well-fitted, do } \\
\text { not protect when mask is removed after the procedure }\end{array}$ \\
\hline $\begin{array}{l}\text { Preprocedural rinse with antiseptic } \\
\text { mouthwash such as } \\
\text { Chlorhexidine }\end{array}$ & $\begin{array}{l}\text { Reduces the bacterial count in the } \\
\text { mouth, saliva and air; inexpensive on a } \\
\text { per-patient basis }\end{array}$ & $\begin{array}{l}\text { Tends to be most effective on free-floating organisms; it will } \\
\text { not affect biofilm organisms such as plaque, sub-gingival } \\
\text { organisms, blood from the operative site or organisms from } \\
\text { the nasopharynx }\end{array}$ \\
\hline High-volume evacuator & $\begin{array}{l}\text { Will reduce the number of bacteria in } \\
\text { the air and remove most of the material } \\
\text { generated at the operative site such as } \\
\text { bacteria, blood and viruses; inexpensive } \\
\text { on a per-patient basis }\end{array}$ & $\begin{array}{l}\text { When an assistant is not available, it is necessary to use a } \\
\text { high-volume evacuator attached to the instrument or a "dry } \\
\text { field" device; a small-bore saliva ejector is not an adequate } \\
\text { substitute }\end{array}$ \\
\hline $\begin{array}{l}\text { High-efficiency particulate air room } \\
\text { filters and ultraviolet } \\
\text { Treatment of ventilation } \\
\text { System }\end{array}$ & $\begin{array}{l}\text { Effective in reducing numbers of } \\
\text { airborne organisms }\end{array}$ & $\begin{array}{l}\text { Only effective once the organisms are already in the room's } \\
\text { air, moderate to expensive, may require engineering } \\
\text { changes to the ventilation system }\end{array}$ \\
\hline
\end{tabular}

of 2019-nCoV with particular attention to door handles, chairs, and elevators suggested. ${ }^{5}$

\section{CONCLUSION}

The outbreak of SARS-CoV-2 within the world wide led to public health emergency round the world. With the" New Normal" due to pandemic, health system will certainly have an overload thereon. It is important that case presentations can be dynamic, and there is a decent possibility that dental practitioners may treat a portion of the patients with asymptomatic COVID-19 contaminations since the incubation period can go from 2 to 14 days and most patients only develops mild symptoms. Thus, every patient should be considered as a potentially infected by virus and need to take universal precautions to minimize the spread of the virus and its associated disease during routine or emergency practice and maintain high standards of care and infection control. Moreover, the aerosol and splatter created during dental procedure can possibly spread disease to dental work force and others in the dental office. While, similarly as with all contamination control techniques, though it's difficult to totally wipe out the hazard presented by dental aerosol, it's conceivable to limit the hazard with moderately basic and inexpensive precautionary measures.

\section{REFERENCES}

1. Fehr AR and Perlman S. Coronaviruses: an overview of their replication and pathogenesis.Methods Mol Biol. 2015; 1282:1-23.

https://doi.org/10.1007/978-1-4939-2438-7_1

2. www.cdc.gov/coronavirus/2019-ncov/symptoms-testing/ symptoms.html

3. World HealthOrganization (2020). Report of the WHO-China joint mission on coronavirus disease 2019 (COVID-19) [online].
Website https://www.who.int/docs/default-source/coronaviruse/ who-china-joint-mission-on-covid-19-final-report.pdf [accessed 8 April 2020]

4. Meng L, Hua F andBian Z. Coronavirus disease 2019 (COVID-19): emerging and future challenges for dental and oral medicine. J Dent Res. 2020;99:481-487.

https://doi.org/10.1177/0022034520914246

5. Peng $X, X u X, L i Y$, Cheng L, Zhou $X$ and Ren B. Transmission routes of $2019-n C o V$ and controls in dental practice. Int J Oral Sci. 2020; 12(1):9. https://doi.org/10.1038/s41368-020-0075-9

6. Chen J. Pathogenicity and transmissibility of 2019-nCoV-a quick overview and comparison with other emerging viruses. Microb Infect.2020; 22(2):69-71. https://doi.org/10.1016/j.micinf.2020.01.004

7. Xu H, Zhong L, Deng J, Peng J, Dan H, Zeng X, et al. High expression of ACE2 receptor of 2019-nCoV on the epithelial cells of oral mucosa. Int J Oral Sci. 2020;12(1):8.

https://doi.org/10.1038/s41368-020-0074-x

8. Screening and Triage at Intake. https://www.cdc.gov/ coronavirus/2019-ncov/hcp/dialysis/screening.html

9. Li ZY and Meng LY. The prevention and control of new coronavirus infectionin department of stomatology. Zhonghua Kou Qiang Yi Xue Za Zhi.2020;55(0):E001. doi: 10.3760/ cma.j.issn.1002-0098.2020.0001. Online ahead of print. Article in Chinese.

10. Izzetti R, Nisi M, Gabriele $M$ and Graziani F. COVID-19 transmission in dental practice: Brief review of preventive measures in Italy. Journal of Dental Research.2020 Apr 17. Online ahead of print. https://doi.org/10.1177/0022034520920580

11. Zemouri $\mathrm{C}$, de Soet $\mathrm{H}$, Crielaard $\mathrm{W}$ andLaheij $A$. A scoping review on bio-aerosols in healthcare and the dental environment. PLoS One.2017; 12(5):e0178007 https://doi.org/10.1371/journal.pone.0178007

12. Wax RS and Christian MD. Practical recommendations for critical care and anesthesiology teams caring for novel coronavirus (2019-nCoV) patients. Can J Anesth/J Can Anesth. 2020;67: 568-576. https://doi.org/10.1007/s12630-020-01591-x

13. Hinds WC. Aerosol technology: Properties, behavior, and measurementof airborne particles. New York: Wiley 1982;6-8 
14. Harrel SK andMolinari J. Aerosols and Splatter in Dentistry. JADA. 2004;135:429-437.

https://doi.org/10.14219/jada.archive.2004.0207

15. Micik RE, Miller RL,Mazzarella MA andRyge G. Studies on dental aerobiology, I: bacterial aerosols generated during dental procedures. J Dent Res. 1969;48(1):49-56. https://doi.org/10.1177/00220345690480012401

16. Kohn WG, Collins AS, Cleveland JL, Harte JA, Eklund KJ andMalvitz DM. Centers for Disease Control and Prevention (CDC). Guidelines for infection control in dental health-care settings. MMWR Recomm Rep. 2003;52(RR-17):16-17.

17. KampfG, Todt D, Pfaender $S$ and Steinmann $E$. Persistence of coronaviruses oninanimate surfaces and its inactivation with biocidal agents. J Hosp Infect.2020; 104(3): 246-251. https://doi.org/10.1016/j.jhin.2020.01.022

18. Geller C, Varbanov M and Duval RE. Human Coronaviruses: Insights into Environmental Resistance and Its Influence on the Development of New Antiseptic Strategies. Viruses.2012;4: 3044-3068.

https://doi.org/10.3390/v4113044

\section{Authors Contributions:}

AT- Conceptualized and designed the study, Critical revision of the manuscript, Interpretation, literature search; MNT- Conceptualized the study, literature search, prepared first draft of the manuscript, review of the study, Manuscript review; RLT- Concept of the study, Interpretation, Manuscript review; M- Literature search, review of the study

\section{Work attributed to:}

Kothiwal Dental College and Research Centre, Department of Public Health Dentistry, Moradabad, India

\section{Orcid ID:}

Dr Amit Tirth- (i) https://orcid.org/0000-0002-6304-775X

Dr Md NazamuddinTafadar- (1) https://orcid.org/0000-0003-4208-4567

Dr Ravishankar Lingesha Telgi- (1) https://orcid.org/0000-0002-2921-4235

Dr Monika- (D) https://orcid.org/0000-0002-8417-8484

Source of support: None, Conflicts of Interest: None 